\title{
Medidas antropométricas orofaciais de crianças paulistanas e norte-americanas: estudo comparativo***
}

\author{
Anthropometric orofacial measurements of children from Sao Paulo \\ and from North America: comparative study
}

\author{
Débora Martins Cattoni* \\ Fernanda Dreux Miranda Fernandes**
}

*Fonoaudióloga. Doutora em Ciências pela Faculdade de Medicina da Universidade de São Paulo. Professora do Centro de Especialização em Fonoaudiologia Clínica (Cefac). Endereço para correspondência: Rua Barão da Passagem, 1330 - Apto 91C São Paulo - SP -

CEP 05087-000

(dmcattoni@uol.com.br)

**Fonoaudióloga. Livre-Docente. Professora Associada do Curso de Fonoaudiologia da Faculdade de Medicina da Universidade de São Paulo. ***Trabalho Realizado na Faculdade
de Medicina da Universidade de São
Paulo

Artigo Original de Pesquisa

Artigo Submetido a Avaliação por Pares

Conflito de Interesse: não

Recebido em 26.05.2008. Revisado em 05.10.2008. Aceito para Publicação em 03.02.2009.

\begin{abstract}
Background: anthropometric orofacial measurements of children from Sao Paulo and from North America. Aim: to describe the anthropometric orofacial measurements of children from Sao Paulo and to compare the obtained means to the North American norms. Method: participants were 254 children, leukoderm, in mixed dentition period, with ages ranging from 7 to 11 years and 11 months, with no history of speech, language and hearing disorders or treatment. The investigated anthropometric orofacial measurements were the height of the upper lip, the height of lower lip, the length of the philtrum and the height of lower face. In order to obtain these measurements, an electronic digital sliding caliper Starrett Series 727 was used. Results: the obtained data for the height of the upper lip, the height of the lower lip and the height of the lower face are below the means described for North American children. When considering the length of the philtrum, similar results were found between the research sample and North American children. Conclusion: the results of the measurements of the present sample referring to the height of the upper lip, the height of the lower lip and height of the lower face are below the values reported for North American children. The North American norms are not valid for the children of our population, except for the length of the philtrum.
\end{abstract}

Key Words: Face; Measurements; Anthropometry; Child; Stomatognathic System.

\section{Resumo}

Tema: medidas antropométricas orofaciais de crianças paulistanas e norte-americanas. Objetivo: descrever medidas antropométricas orofaciais em crianças paulistanas e comparar as médias dessas medidas com os padrões de normalidade publicados para a população norte-americana. Método: participaram 254 crianças, leucodermas, em dentição mista, com idades entre 7 e 11 anos e 11 meses, sem histórico de distúrbios ou tratamento fonoaudiológicos. As medidas antropométricas orofaciais coletadas foram a altura do lábio superior, a altura do lábio inferior, o comprimento do filtro e a altura do terço inferior da face. $\mathrm{O}$ instrumento utilizado foi um paquímetro eletrônico digital Starrett Series 727. Resultados: os dados obtidos nesta amostra para a altura do lábio superior, altura do lábio inferior e altura do terço inferior da face encontram-se abaixo das médias descritas para as crianças norte-americanas. Os resultados desta amostra, referentes ao comprimento do filtro, coincidem com as médias descritas para as crianças norteamericanas. Conclusão: os resultados das medidas da presente amostra referentes a altura do lábio superior, altura do lábio inferior e altura do terço inferior da face foram menores do que aqueles publicados para as crianças norte-americanas. Os dados de normalidade da população norte-americana não são válidos para as crianças da nossa população, exceto para o comprimento do filtro.

Palavras-Chave: Face; Medidas; Antropometria; Criança; Sistema Estomatognático. 


\section{Introduction}

Anthropometry is the biological science of measuring the size, weight and proportion of the human body (1) and provides objective data to the craniofacial morphology evaluation, through a series of head and face measurements (2). The anthropometry presents many advantages to the evaluation of craniofacial morphology by using simple, noninvasive, low-risk and inexpensive techniques. It is an important clinical tool due to its simplicity, besides providing reference normality data about a great variety of facial measurements of the Caucasian population (3-5).

Facial morphologic differences are described in studies of different populations because the craniofacial complex, specially the face, is one of the most varying parts of the human body (6-8). Therefore, it is important to use references based on race correspondent populations. With this perspective, Farkas and Deutsch (9) state that the validity of normal measurements necessarily depends of the comparison with appropriate population norms. It is extremely important that the clinic understands that the population norms of a given group are not necessarily valid to other samples or groups, specially when there are geographic and racial variations (10).

In respect to anthropometric orofacial measurements, the height of the upper lip (sn-sto) corresponds to the distance between the subnasale (sn) and the stomion (sto) $(1,11)$. The heigth of the lower lip (sto-gn) is the distance between the stomion (sto) and the gnathion (gn) (11). The length of the philtrum (sn-ls) corresponds to the distance between the subnasale (sn) and the labiale superius (ls) (1). The heigth of the lower face (sn-gn) is the distance between the subnasale (sn) and the gnathion (gn) $(12,13)$.

On a research with healthy Caucasian North American population, it was observed that height of the upper lip (sn-sto) is between 18,7 e 19,9 millimeters $(\mathrm{mm})$ at 6 years old, with a small growth until 12 years old (measurements between 19,9 and $20,9 \mathrm{~mm}$ ). The authors also suggest that the heigth of the lower lip (sto-gn) measures between 40 and $41 \mathrm{~mm}$ at 6 years old, increasing to $44 \mathrm{~mm}$ at 12 years old. They also described that the length of the philtrum (sn-ls) measures between 12,6 and 14,44mm at 6 years old and 14,4mm with 12 years old (14).

The interest to the proposition of this research has grown as it was observed the lack of studies that determine if the international reference values of the anthropometric orofacial measurements can be applied to our population. The purpose of this research was to describe anthropometric orofacial measurements in children from Sao Paulo and to compare the mean of these measurements with North American norms.

\section{Methods}

Caregivers authorized the data collection by signing the informed consent form approved by the institution's committee for Ethics and Research from the Faculty of Medicine of University of Sao Paulo (protocol number 668/01). Subjects were 254 children with ages between 7 years and 11 years and 11 months, being 137 boys (54\%) and 117 girls $(46 \%)$, attending private schools of the city of Sao Paulo.

Children were divided in five groups according to their ages: 48 children between 7 years and 7 years and 11 months; 52 with ages varying between 8 years and 8 years and 11 months; 50 children between 9 years and 9 years and 11 months; 54 children between 10 years and 10 years and 11 months and 50 children between 11 years and 11 years and 11 months.

Inclusion criteria to this study were: leukoderm and mixed dentition period, with complete eruption of the first permanent molars. Exclusion criteria were: audiologic, speech or language complaints, prior or current speech pathology treatments and history of syndromes and/or neurologic diseases and/or bifid uvula.

The instrument used to obtain the anthropometric orofacial measurements was the electronic digital sliding caliper Starrett Series 727, made in Brazil, made of steel and with LCD display with unit system in milimetres and resolution and repeatability of $0,01 \mathrm{~mm}$.

During data collection it was asked that the children remained seated with both feet on the ground, with the head in resting position and closed lips. The anthropometric orofacial measurements obtained from each child were: heigth of the upper lip (from the subnasale to the stomion or sn-sto); heigth of the lower lip (from the stomion to the gnathion or sto-gn); length of the philtrum (from the subnasale to the labiale superius or sn-ls) and heigth of the lower face (from the subnasale to the gnathion or sn-gn). Subsequently, analysis were made in order to compare anthropometric orofacial measurements between children from Sao Paulo and from North American, according to North American norms, published by Farkas et al. (14). 
Statistical Analysis

The comparison between the averages of anthropometric orofacial measurements separated boys and girls, according to the ages. To each anthropometric measure the confidence interval of 95\% was determined. All analysis were processed with SPSS for Windows version 12.0 and the considered level of significance was $5 \%$.

\section{Results}

1016 anthropometric orofacial measurements were obtained.

In respect to the heigth of the upper lip (sn-sto) and to the heigth of the lower lip (sto-gn), it is possible to observe that the means values obtained in the present study were always smaller than those obtained in researches by Farkas et al. (14). Those have values that are above the confidence interval obtained in the present study on all age groups and for both subjects of both genders. It can be concluded, by this data, that the mean values of the upper lip (sn-sto) and the lower lip (sto-gn) identified by Farkas et al. (14) are statistically larger than those of the present sample. In respect to the length of the philtrum (sn-ls), the mean values described to North American children are within the confidence value obtained by the present research to boys of 7, 8 and 9 years old. The data obtained by the present study coincide with the results presented in researches by Farkas et al. (14) (Table 1).

On Table 2, it can be noted that in respect to the heigth of the lower face (sn-gn) all means determined by Farkas et al. (14) are above the confidence interval identified in the present study, on all age groups and on both genders. These results suggest that there are statistically significant differences between the means from the both populations.

TABELA 1. Comparação das medidas antropométricas orofaciais da região nasolabial.

\begin{tabular}{|c|c|c|c|c|}
\hline \multicolumn{5}{|c|}{ Heigth of upper lip (sn-sto) } \\
\hline \multirow[t]{2}{*}{ Sex } & Age (years) & Mean $(\mathrm{mm})$ & IC 95\% (mean) & Mean $(\mathrm{mm})$ \\
\hline & & Children from Sao Paulo & & Children from North America \\
\hline \multirow{5}{*}{ Male } & 7 & 18,45 & $17,81-19,08$ & 19,30 \\
\hline & 8 & 18,51 & $17,83-19,19$ & 19,70 \\
\hline & 9 & 18,58 & $17,93-19,22$ & 19,30 \\
\hline & 10 & 18,53 & $17,87-19,18$ & 20,30 \\
\hline & 11 & 18,85 & $18,21-19,49$ & 20,80 \\
\hline \multirow{5}{*}{ Female } & 7 & 17,54 & $16,74-18,34$ & 18,80 \\
\hline & 8 & 17,34 & $16,69-18,00$ & 19,00 \\
\hline & 9 & 17,57 & $16,84-18,29$ & 19,20 \\
\hline & 10 & 17,76 & $17,10-18,41$ & 19,60 \\
\hline & 11 & 17,63 & $16,90-18,36$ & 19,40 \\
\hline \multicolumn{5}{|c|}{ Heigth of lower lip (sto-gn) } \\
\hline \multirow[t]{2}{*}{ Sex } & Age (years) & Mean $(\mathrm{mm})$ & IC $95 \%$ (mean) & Mean $(\mathrm{mm})$ \\
\hline & & Children from Sao Paulo & & Children from North America \\
\hline \multirow{5}{*}{ Male } & 7 & 39,26 & $38,15-40,37$ & 42,40 \\
\hline & 8 & 39,14 & $37,95-40,34$ & 42,20 \\
\hline & 9 & 39,19 & $38,06-40,32$ & 42,40 \\
\hline & 10 & 41,04 & $39,89-42,19$ & 43,30 \\
\hline & 11 & 42,05 & $40,92-43,17$ & 44,00 \\
\hline \multirow{5}{*}{ Female } & 7 & 37,38 & $35,98-38,79$ & 40,70 \\
\hline & 8 & 38,25 & $37,10-39,39$ & 40,60 \\
\hline & 9 & 39,20 & $37,93-40,47$ & 40,90 \\
\hline & 10 & 39,96 & $38,80-41,10$ & 42,50 \\
\hline & 11 & 41,05 & $39,78-42,32$ & 42,20 \\
\hline \multicolumn{5}{|c|}{ Length of the philtrum (sn-ls) } \\
\hline \multirow[t]{2}{*}{ Sex } & Age (years) & Mean $(\mathrm{mm})$ & IC 95\% (mean) & Mean (mm) \\
\hline & & Children from Sao Paulo & & Children from North America \\
\hline \multirow{5}{*}{ Male } & 7 & 13,32 & $12,70-13,94$ & 13,70 \\
\hline & 8 & 13,48 & $12,81-14,15$ & 14,00 \\
\hline & 9 & 13,20 & $12,57-13,83$ & 13,30 \\
\hline & 10 & 13,66 & $13,02-14,31$ & 14,40 \\
\hline & 11 & 13,74 & $13,11-14,38$ & 14,50 \\
\hline \multirow{5}{*}{ Female } & 7 & 13,00 & $12,22-13,79$ & 12,90 \\
\hline & 8 & 12,70 & $12,06-13,34$ & 13,20 \\
\hline & 9 & 12,10 & $11,38-12,81$ & 13,40 \\
\hline & 10 & 12,96 & $12,31-13,60$ & 12,70 \\
\hline & 11 & 12,74 & $12,02-13,45$ & 13,00 \\
\hline
\end{tabular}

Legend: $\mathrm{mm}=$ milimeters; $\mathrm{IC}=$ confidence interval. 
TABLE 2. Comparison of heigth of the lower face (sn-gn).

\begin{tabular}{|c|c|c|c|c|}
\hline Sex & Age (years) & Mean (mm) & IC 95\% (mean) & Mean (mm) \\
\hline & & Children from Sao Paulo & & Children from North America \\
\hline \multirow{5}{*}{ Male } & 7 & 58,48 & $57,16-59,80$ & 61,10 \\
\hline & 8 & 58,43 & $57,01-59,84$ & 61,90 \\
\hline & 9 & 58,68 & $57,34-60,03$ & 61,70 \\
\hline & 10 & 60,92 & $59,55-62,28$ & 63,50 \\
\hline & 11 & 61,69 & $60,35-63,03$ & 65,30 \\
\hline \multirow{5}{*}{ Female } & 7 & 55,67 & $54,00-57,32$ & 59,70 \\
\hline & 8 & 56,76 & $55,40-58,13$ & 59,30 \\
\hline & 9 & 57,77 & $56,25-59,28$ & 59,90 \\
\hline & 10 & 58,93 & $57,57-60,30$ & 62,20 \\
\hline & 11 & 59,47 & $57,96-60,99$ & 62,10 \\
\hline
\end{tabular}

Legend: $\mathrm{mm}=$ milimeters $; \mathrm{IC}=$ confidence interval .

\section{Discussion}

The researchers opted by the methodology described by classical anthropometric studies (1$3,5,15-19)$. In respect to the criteria for the children selection, it was considered the researches described by several authors (2,15-17,20-21). It was also selected only leukoderm children as in some studies (14,16-18), because some report facial measurements differences with multi-racial samples (7-9,22).

As it was possible to observe in this sample, the mean determined to heigth of the upper lip (sn-sto), to heigth of the lower lip (sto-gn) and to heigth of the lower face (sn-gn) were smaller on all age groups and on both gender, than those reported to North American population (14). The means obtained by this author are above the means and the confidence intervals of the present study, suggesting that the heigth of the upper lip (sn-sto) is larger in North American population.

The results obtained in this study referring to the length of the philtrum (sn-ls) coincide with the ones obtained by Farkas et al. (14]), indicating that this structure has the same height in North American population and in this population.
This research has some limitations, because it compares two specific populations and also because the sample is relatively restricted; it should be an important step for future investigations.

The knowlegde about orofacial measurements of children, and also its variations referring to the origin, verifying if there are statistically differences among different populations, brings precision in the results analysis. Moreover, it contributes to orofacial motricity evaluation and to establish the functional diagnosis done by the speech language pathologist, due to the possibility to quantify the structures of the face and to provide objective data about the orofacial morphology.

\section{Conclusions}

The results obtained to children from Sao Paulo to the heigth of the upper lip, heigth of the lower lip and heigth of the lower face (sn-gn) are below the means reported to North American children. The results to length of the philtrum coincide in the both studied populations. 


\section{References}

1. Farkas LG. Examination. In: Farkas LG, editor. Anthropometry of the head and face. 2nd ed. New York: Raven Press; 1994. p. 3-56.

2. Ward RE, Jamison PL, Farkas LG. Craniofacial variability index: a simple measure of normal and abnormal variation in the head and face. Am J Med Genet. 1998;80(3):232-40.

3. Ward RE. Facial morphology as determined by anthropometry: keeping it simple. J Craniofac Genet Dev Biol. 1989;9:45-60.

4. Allanson JE. Objective techniques for craniofacial assessment: what are the choices? Am J Med Genet. 1997;70:1-5.

5. Ward RE, Jamison PL, Allanson JE. Quantitative approach to identifying abnormal variation in human face exemplified by a study of 278 individuals with five craniofacial syndromes. Am J Med Genet. 2000;91(1):817.

6. Farkas LG, Ngim RCK, Venkatadri G. Racial and ethnic morphometry differences in the craniofacial complex. In: Farkas LG, editor. Anthropometry of the head and face. 2nd ed. New York: Raven Press; 1994. p. 201-18.

7. Borman H, Ozgur F, Gursu G. Evaluation of soft-tissue morphology of face in 1,050 young adults. Ann Plast Surg. 1999;42(3):280-8.

8. Le TT, Farkas LG, Ngim RCK, Levin S, Forrest CR. Proportionality in Asian and north American Caucasian faces using neoclassical facial canons as criteria. Aesth Plast Surg. 2002;26(1):64-9.

9. Farkas LG, Deutsch CK. Anthropometric determination of craniofacial morphology [editorial]. Am J Med Genet. 1996;65(1):1-4.

10. Enlow DH, Hans MG. Noções básicas de crescimento facial. São Paulo: Santos; 1998. p. 304.

11. Suguino R, Ramos AL, Terada HH, Furquim LZ, Maeda L, Silva Filho OG. Análise facial. R Dental Press Ortodon Ortop Maxilar. 1996;1(1):86-107.

12. Psillakis JM, Lucardi V. Proporções estéticas da face. In: Psillakis JM, Zanini AS, Mélega JM, Costa EA, Cruz RL. Cirurgia craniomaxilofacial: osteotomias estéticas da face. Rio de Janeiro: Medsi; 1987. p. 297-313.
13. Gregoret J. Ortodontia e cirurgia ortognática: diagnóstico e planejamento. São Paulo: Santos; 1999.

14. Farkas LG, Hreczko TM, Katic MJ. Craniofacial norms in north American Caucasians from birth (one year) to young adulthood. In: Farkas LG, editor. Anthropometry of the head and face. 2nd ed. New York: Raven Press; 1994. p. 241-312.

15. Farkas LG, Hreczko TA, Kolar JC, Munro IR. Vertical and horizontal proportions of the face in young adult north American Caucasians: revision of neoclassical canons. Plast Reconstr Surg. 1985;75(3):328-37.

16. Farkas LG, Posnick JC. Growth and development of regions units in the head and face based on anthropometric measurements. Cleft Palate-Craniofac J. 1992;29(4):3012 .

17. Farkas LG, Posnick JC, Hreczko TM. Growth patterns of the face: a morphometric study. Cleft Palate-Craniofac J. 1992;29(4):308-15.

18. Farkas LG, Posnick JC, Hreczko TM, Pron GE. Growth patterns of the nasolabial region: a morphometric study. Cleft Palate-Craniofac J. 1992;29(4):318-24.

19. Shaner DJ, Bamforth S, Peterson AE, Beattie OB. Technical note: different techniques, different results comparison of photogrammetric and caliper-derived measurements. Am J Phys Anthropol. 1998;106(4):54752.

20. Ward RE, Jamison PL. Measurement precision and reliability in craniofacial anthropometry: implications and suggestions for clinical application. J Craniofac Genet Dev Biol. 1991;11:156-64.

21. Ferrario VF, Sforza C, Poggio CE, Schmitz JH, Colombo A. Soft-tissue facial morphology related to headform: a three-dimensional quantitative analysis in childhood. J Craniofac Genet Dev Biol. 1997;17:86-95.

22. Farkas LG, Forrest CR, Litsas L. Revision of neoclassical facial canons in young adult Afro-Americans. Aesth Plast Surg. 2000;24(3):179-84. 